\title{
Influence of Covid 19 Pandemic on Health Educators' Job Commitment in Federal and State Owned Colleges of Education in Delta State
}

\author{
Okudaye, I.N (Ph.D) \\ Colleges of Education, Agbor, Delta State
}

\begin{abstract}
This study was undertaken to investigate influence of COVID 19 pandemic on health educators' job commitment in federal and state owned colleges of education in Delta state. The study employed descriptive survey design. The population was 77 health educators in the four Federal and State Colleges of Education in Delta State. The researcher sampled the entire 77 teachers because of their fewness. The instrument for the investigation was titled "Influence of Covid 19 Pandemic on Health educators' Job Commitment Questionnaire (ICHLJCQ). On the whole, the worth of Pearson Product Moment Correlational Coefficient (r) for COVID 19 pandemic was 0.77. Out of entire copies of 77 instruments administered, 75 instruments were retrieved. Male health educators was 53 and female health educators 22 . The descriptive data of mean rating and standard deviation were employed to respond to the 5 research questions. Mean rating of 2.50 was assumed as the significant level of receipt as mean rating below 2.50 was discarded. $\mathrm{z}$ - test was employed to test the 5 null hypotheses formulated that direct the investigation at 0.05 levels of significance. Findings showed that influence of COVID 19 pandemic on health educators' job commitment in Federal and State owned Colleges of Education in Delta State was high. Influence of utilisation of prevention, college support on the utilisation of prevention against COVID 19 pandemic and health educator's job commitment in Federal and State owned Colleges of Education in Delta State was low. The level of awareness of utilisation of preventions against COVID 19 pandemic ,the level of utilisation of preventions against COVID 19 pandemic on health educators , job commitment in federal and state owned colleges of education in Delta state was low. There was no significant difference on influence of COVID 19 pandemic, utilisation of prevention against COVID 19 pandemic, College support, level of awareness and level of utilisation of preventions against COVID 19 pandemic on health educators' job commitment in federal and state owned colleges of education in Delta state. It was concluded in the study that there was no significant difference on influence of COVID 19 pandemic, utilisation of prevention against COVID 19 pandemic, College support the level of awareness of utilisation of preventions against COVID 19 pandemic and level of utilisation of preventions against COVID 19 pandemic on health educators 'job commitment in federal and state owned colleges of education in Delta State. It was as well recommended that commitment should be shown on prevention of COVID 19 pandemic by health educators in Federal and State owned Colleges of Education in Delta State . Health educators should enhance their commitment to prevention of COVID 19 pandemic to enhance their job commitment in Federal and State owned Colleges of Education in Delta State.
\end{abstract}

Keywords: Colleges of Education COVID 19 Pandemic, Delta State Federal and State Owned, Health Teachers, Influence, Job Commitment.

DOI: $10.7176 / \mathrm{JEP} / 12-18-08$

Publication date:June $30^{\text {th }} 2021$

\section{Introduction}

The Colleges of education are one of the most significant communal institutions in civilisation. It is one of the post-secondary institutions in Delta state, planned purposely to prepare students for teaching. . Colleges of education are expected to produce individuals who are balanced and refined in all aspects of human endeavor, academically, socially, psychologically and otherwise (Ganagana \& Splent-Martina, 2017). Health education is one of the major components of primary healthcare (Suoke, 2013).

The Federal Republic of Nigeria (2014) in her National Policy on Education affirmed the rationale of health education programme comprises generating extremely aggravated, reliable and competent health educators for every levels of education; heartening more the courage of enquiry and originality in health educators ; helping health educators to fit into the communal life of the neighborhood and civilisation in general and improving their commitment to national goals; offering educator s with the scholarly and specialised setting satisfactory for their job and to make them adjustable to any altering circumstances not just in the existence of their nation, but in the globe and enhancing educator s' commitment to their job. Health education cannot be on awareness only, it must inspire health educators towards healthy livelihood (Ogbe , 2014). Healthy and creative health educators are key contributors to the strength, financial development and continued existence of any nation Nabofa \& Dada , 2013). 
The colleges requires health educators who are committed to the worth and objectives of the colleges. Efficiency of health education programme in the colleges is directly linked to health educators' job commitment which results from their mental contentment. They should be contented with the colleges in which they perform (Cole \& Bruch 2016). A number of authors were concerned about if commitment was a rational anticipation for health educators in colleges of education where alteration in administration and their focal point may happen fast (Caudron, 2016). Health education has continued globally with steady growth in investigations. There are constant investigations in the region of preventive health for attitudinal alteration and behavior. Job protection entails secure, comparatively expected institutions in which health educators might perform their job devoid of disruption, impairment, threat and harm. Adebayo (2013) noted that the fright of academic staff of higher institutions in Nigeria is that they are not safe in the institutions. Ogunyemi and Aliyu (2011) noted that there is inadequate protection against infectious diseases given to health educators in their job performance in higher institutions of learning in Nigeria.

Protection of health educators against COVID 19 pandemic in the $21^{\text {st }}$ century enhances their job commitment. Meyer and Allen (2017) suggested that the commitment can be conceptualised as types of aspirations such as emotional, responsibility and persistence commitment. Health teachers needs to be protected against COVID 19 pandemic in their job performance .In an inquiry, Meyer, Paunonen, Gellatly, Goffin and Jackson (2019) found that there was significant relationship between provision of protections equipment against infectious diseases and health educator's job commitment. Health educators in the colleges need protection against COVID 19 pandemic in their job performance. Eisenberger, Huntington, Hutchison and Sowa (2016) noted that health educators' views of colleges of education commitment to them in terms of provision of protections is Alleged College support, based on health educators' overall attitude about the level to which the colleges worth their assistance and cares concerning their protection against COVID 19 pandemic. They further affirmed that health educators who distinguish an elevated height of College support are further prone to sense a responsibility to "pay back" the colleges in terms of emotional commitment and job-related actions.

Colleges of Education issues form the basis of the institution and recline in both the institution and the teachers (Rickli \& PerdeckNolost, 2012).

In an exploration, Burleson and Thoron (2014) found that protection against infectious diseases on the job significantly relate with health educators job commitment

Consciousness can influence the observation of health educators due to their past understanding and approaches (Oppenheim, Lidow, Ayscue, Saylors, Mbala \& Kumakamba , 2019) .

In an investigation, Meyer and Allen (2011) found that emotional institutional commitment has insinuation for scheduled job behaviour since it is a psychological condition. Protection is emotion of security from hurt or hazard, the defense and surveillance of major worth and the lack of fear to obtained ideals (Dania \& Eboh, 2013). Health educators wellbeing and performance optimization are the basis of an efficient existence in any unsafe college setting (Jones, O'Connor, Deuster, Peck, Shake \& Frost , 2010). In an analysis, Ingersoll and May (2011) found that health educators frequently depart teaching job as they are discontented with a protection given to them. Marzano, Waters, and McNulty (2005) noted that in order for colleges of education to thrive, colleges of education administrators must perform efficiently and as well support health educators. Protection of life and possessions is a basic human right guaranteed under the Nigerian constitution. Protection requirements embrace security against COVID 19 pandemic in the colleges of education in Delta state. Devoid of protection health educators against infectious diseases in teaching, our vision of connecting the influence of schooling for attaining objective of quality wellbeing will appear nil. Eisenberger etal. (2016) advocated health educator's opinion of the college obligation to them in a period of outbreak of infectious diseases as alleged college sustenance based on health educators' attitudes about the degree to which the colleges of education appreciate their assistance and are bothered about their protection against viruses. Health educators who recognized an elevated extent of colleges of education sustenance are further prone to consider an commitment to "pay back" the colleges , based on job commitment and connected behaviour .

The Nigerian Labour Congress (2012) noted that despite actions taken by Delta state government; the protection condition in Deltans persists to be bad in areas such as COVID 19. Mental agreements are the shared attitude, insight, and unceremonious requirements between colleges of education authorities and health educators (Mullins, 2017). Good mental agreements boast inherent and extrinsic inspiration of health educators. Furthermore, mental agreement boost ranges of job results protection, contentment, accountability and welldesigned suppleness (Robbins \& Judge, 2019)

\section{State of the Problem}

Colleges of education in Delta state is anticipated to fashion gradaunts with sufficient academic preparation and significant useful expertise to make them useful and self-sufficient. The effective teaching among health educators entails adequate protection against COVID 19 pandemic in the colleges to enhance their job performance. Health educators are presently faced with problem of COVID 19 pandemic. They are as well at 
elevated threat of receiving the disease and the basis of spread in the neighborhood. Some of the teachers are uninformed of the necessary data on the virus with many of them holding persistently to numerous erroneous beliefs. These misinformation guides to their wrong orientation and often results in wrong decisions. Many of them are exposed to COVID-19 and they do not wash their hands with soap and water, they do not use face masks, not isolated from people

Research Questions: To guide study, the following research questions were raised:

1 What is the influence of COVID 19 pandemic on health educators' job commitment in Federal and State owned Colleges of Education in Delta State?

2 What is the influence of utilisation of prevention against COVID 19 pandemic on health teachers, job commitment in Federal and State owned Colleges of Education in Delta State?

3 What is the influence of College support on the utilisation of prevention against COVID 19 pandemic and health teacher's job commitment in Federal and State owned Colleges of Education in Delta State?

4 What is the level of awareness of utilisation of preventions against COVID 19 pandemic on health educators' job commitment in federal and state owned colleges of education in Delta state?

5. What is the level of utilisation of preventions against COVID 19 pandemic on health educators' job commitment in federal and state owned colleges of education in Delta state

\section{Hypotheses}

The following null hypotheses were formulated to guide the study:

1 There is no significant difference on influence of COVID 19 pandemic on health educators , job commitment in Federal and State owned Colleges of Education in Delta State.

2 There is no significant difference on influence of utilisation of prevention against COVID 19 pandemic on health teachers' job commitment in Federal and State owned Colleges of Education in Delta State.

3 There is no significant difference on influence of College support on the utilisation of prevention against COVID 19 pandemic on health teachers job commitment in Federal and State owned Colleges of Education in Delta State.

4 There is no significant difference on influence of the level of awareness of utilisation of preventions against COVID 19 pandemic on health educators, job commitment in federal and state owned colleges of education in Delta state .

5. There is no significant difference on influence of level of utilisation of preventions against COVID 19 pandemic on health educators' job commitment in federal and state owned colleges of education in Delta state .

\section{Purpose of the Study}

This study investigated influence of COVID 19 pandemic on health educators 'job commitment in Federal and State owned Colleges of Education in Delta State. Principally the study examined:

1 Influence of COVID 19 pandemic on health educators' job commitment in Federal and State owned Colleges of Education in Delta State.

2 Influence of utilisation of prevention against COVID 19 pandemic on health teachers' job commitment in Federal and State owned Colleges of Education in Delta State.

3 Influence of College support on the utilisation of prevention against COVID 19 pandemic on health educator's job commitment in Federal and State owned Colleges of Education in Delta State.

4 The level of awareness of utilisation of preventions against COVID 19 pandemic on health educators' job commitment in Federal and State owned Colleges of Education in Delta State.

5. The level of utilisation of preventions against COVID 19 pandemic on health educators' job commitment in Federal and State owned Colleges of Education in Delta State.

6 Difference on influence of COVID 19 pandemic on health educators' job commitment in Federal and State owned Colleges of Education in Delta State.

7 Difference on influence of utilisation of prevention against COVID 19 pandemic on health teachers ' job commitment in Federal and State owned Colleges of Education in Delta State.

8 Difference on influence of College support on the utilisation of prevention against COVID 19 pandemic on health educator's job commitment in Federal and State owned Colleges of Education in Delta State.

9 Difference on influence of the level of awareness of utilisation of preventions against COVID 19 pandemic on health educators' job commitment in federal and state owned colleges of education in Delta state .

10. Difference on influence of level of utilisation of preventions against COVID 19 pandemic on health educators ' job commitment in federal and state owned colleges of education in Delta state .

Review of Related Literature.

Theoretical Framework: The theories used in this study was and Stufflebeam (1971) Background Contribution 
Procedure and Result Replica of Assessment Abraham Maslow (1943) Hierarchy of Needs.

Stufflebeam (1971) Background Contribution Procedure and Result Replica of Assessment.

The theory used in this study was Stufflebeam (1971) Background Contribution Procedure and Results Replica of Assessment. It is a judgment facilitation replica deemed by the investigator to be appropriate to colleges of education. The replica has four major aspects which are background, contribution, procedure, and result assessment. Background Contribution Procedure and Results replica of assessment based on decision- making. It is a structure and macro based replica. The background assessment provides planning assessment by recognising unmet wants, unexploited openings and fundamental dilemmas that thwart the achievement of desires or the utilisation of openings. Contribution assessment provides organising assessment by analyzing option routine plan of workforce. Procedure assessment provides applying assessment by scrutinising commitment .Results assessment provides reprocessing assessment by shaping the extent to which goals have been attaining and shaping the basis of the achieved outcome. In this investigation, the Background Contribution Procedure and Results replica of assessment was utilised to scrutinise influence of covid 19 pandemic on health educators ' job commitment

Abraham Maslow (1943) Hierarchy of Desires. Maslow (1943) hierarchy of desires is a hypothetical theory that illustrated a structure for general existence contentment. Created in a pyramidal form with five stages, Maslow's theory can be perceived as a hierarchy. Maslow's hierarchy of desires started with physiological desires, followed by protection, belongingness, affection, respect and self-actualization desires. Maslow proposed that desires of the lesser stages must be achieved prior to any successive desires can be achieved (Maslow, 1943). He noted that physiological desires such as food, shelter, and water are the lesser stage on the hierarchy. He further noted that these desires are fundamental for continued existence and are the necessary structure for additional contentment stages. Utilizing Maslow's theory entrance to wellbeing would both please the physiological desires that a health educators would desire to advance to protection stage. Protection desires are at the hub of the human strength. Maslow (1943) proposed that health educators could be deemed to be in a steady condition of searching for protection. Maslow's protection desires could be linked with health educators feeling of protection against COVID 19 pandemic.

Difference on Influence of COVID 19 Pandemic on Health educators' Job Commitment.

Numerous job stressors guides health teachers to detached from the job which as well negatively influence students' academic performance (Steinhardt, Smith Jaggers, Faulk, \& Gloria, 2011).

In an exploration, American Center for Disease Control (2020) established that simple hand hygiene when performed well reduces COVID 19 pandemic among health educators . In a related examination, Sutcher, Darling-Hammond and Carver-Thomas (2016) established that job nuisance, mainly transferable viruses was the major reason why health educators eagerly stop teaching job. In a related inquest, Peters and Waterman (2013) instituted that there was significant association between infectious diseases control and exploitation of prevention and among health workers.

In a comparable discovery, Hanmore, Maclaine, Garin, Alonso, Leroy and Ruff (2013) found that organised infectious diseases control actions covered extensively from succeeding morbidity and death, prevention of diseases to enhancing a cost well-organised healthcare.

Difference on Influence of Utilisation of Prevention Against COVID 19 Pandemic on Health Teachers Job Commitment.

In a further inquisition, National HIV Sero-Prevalence Sentinel Survey (2003) established that health educators do not employ sufficient preventions devices to ensure that they are not infected by virus. In a comparable investigation, Lee, Park, Chung, Lee, Kang, and Lee (2014) instituted that hand hygiene with appropriate instrument significantly relate with infectious diseases control among health educators .

In an additional inquiry, Iliyasu, Dayyab, Habib, Tiamiyu, Abubakar, Mijinyawa and Habib (2020) found that health educators were more well-informed of the certainty that hand hygiene is the most efficient technique of infectious disease control. They additionally established that avoiding reusing needles, use of protection devices and hand hygiene capably control infectious disease among health educators . In an alike inquest, Kampf , Löffler and Gastmeier (2009) ascertained that improved compliance in hand hygiene with normal alcohol-based sanitiser can reduce the virus infection by $40 \%$. In a related search, The World Health Organisation (2020) found that over 80\% of Covid-19 patients have little awareness of their infection of COVId 19 pandemic. $20 \%$ of infected health workers had a cruel infirmity such as smallness of inhalation, contaminated distress and organ breakdown. It was reported that an anticipated $2 \%$ of cases can be fatal.

Difference on Influence of College Support on the Utilisation of Prevention Against COVID 19 Pandemic on Health educators Job Commitment.

Colleges of education support are the extent to which health educators consider that their colleges will support them in the provision and utilisation of prevention against COVID 19 pandemic. Numerous issues might persuade health educators' remaining in teaching. They are College administrator's support, protection, inadequate utilisation of prevention measures, classroom' administration and autonomy (Mee \& Haverback, 
2014). In an investigation, Sutcher et al. (2016) established that administrative support, students' actions , inadequate decision-making power, and insufficient use of preventive measures against communicable diseases , influence negative teachers job commitment. In a similar study, Boe, Cook and Sunderland (2008) found that inadequate use of prevention against infectious disease by health educators made many of them to quit teaching . In an inquiry, Ingersoll (2014) found that most health educators departed teaching due to job displeasure as they preferred enhanced jobs, use of prevention and other openings. In a related investigation, Margolis (2008) observed that certain group's health educators who are at a crisis in teaching are deeply persuaded by the support from their college administrators. In an exploration, Greenlee and Brown (2009) instituted that the college of education administrator's ability of efficiently structuring the wellbeing of their health educators to be committed in teaching was low.

Inadequate support by colleges of education administrators on protections against infectious diseases enhanced negatively health educators job commitment (Sass, Seal \& Martin, 2010), 2010). Greenlee and Brown (2009) noted that colleges of education administrators should provide job requirement of their teachers to progress their job performance and commitment. In an investigation Shaw and Newton (2014) found that there was a significant and positive relationship between the level that health educators alleged colleges of education administrators and their personal job contentment.

In an investigation, Mathieu and Zajac (2010) found that Colleges of education were committed to the provision and use of preventions against infectious diseases for health educators. In a similar study, Mottaz (2018) found that there was a significant and positive association between alleged College support in the provision and use of preventions against infectious diseases and health educator's job commitment. Eisenberger, Huntington, Hutchison and Sava (2016) establish that health educators exchange ommitment to the Colleges of education for greater care, concern, and support from the colleges. These findings raise questions about the role of the colleges in terms of what the colleges should provide to health educators. Colleges of education support are an important factor with respect to health educator's behaviour. In their studies, they establish that there is a positive correlation between Colleges of education support and health educators' job commitment. In an investigation, Hawkins (2018) established that colleges commitment of health educators is clarified by alleged

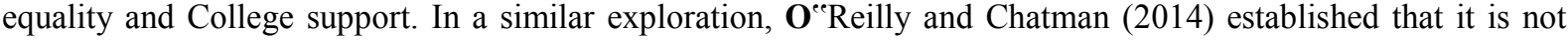
likely to establish decisively if alleged College support persuade the discrepancy of outcome.

Difference on Influence of the Level of Awareness of Utilisation of Preventions Against COVID 19 Pandemic on Health educators' Job Commitment.

The health educators acquires awareness, approaches, beliefs and practice on preventive measures against infectious diseases (Imogie , 2019). Health institutions and scientists have cautioned that prevalent propaganda on COVID-19 is a grave issue causing intolerance globally. Health educators should cautiously appraise COVID-19 connected data and should utilize logical and genuine content as data basis(Shimizu 2020).

This apparent lack of knowledge

could result in delays in the implementation of necessary

confinement measures and personal protective equipment, which

may increase the burden of COVID-19.

In a study, Bamigboye and Adesanya (2006) affirmed that there was elevated height of awareness among health educators. $77 \%$, of health educators , $61 \%$, with just $18.9 \%$ of the health educators observed that worldwide infectious diseases protection devices featured in their teaching. In a comparable investigation, Gadzama, Bawa, Ajinoma, Saidu and Umar (2014) recognised that there was discrepancy among health workers in terms of level of awareness of infectious diseases multiplication, management, acceptance and application by health educators . In a comparable inquiry, Ogoina , Pondei, Chima , Isichei and Gidado (2015) found that there was a significant difference in the level awareness of infectious diseases prevention based on their grade level and job experience of health educators . In a akin inquest, In a similar investigation, Abdullah and Allen (2016) discovered that that health educators had insufficient awareness and approaches towards infectious diseases management. In an alike study, Bhagavathula, Aldhaleei, Rahmani, Mahabadi, Bandari (2020) found that 276 health educators who were respondents $(61.0 \%)$ had insufficient awareness level of broadening and signs ; 288 respondents $(63.6 \%)$ have high level of awareness of Covid-19. Additional discovery showed that age of health educators significantly relate with their level of awareness of Covid-19 pandemic and prevention measures.

In a similar study, Giao Thi, Han, Khanh3, Ngan, Tam and An (2020) found that level of awareness and advancement towards Covid-19 among health educators was low. In another examination, Egwuenu and Okanlawon (2014) ascertained that health educators in the investigation had awareness of infectious diseases management, but not totally replicated in the level of their awareness' of diseases preventions. Most of them were aware that washing of hands with soap and water (97.8\%), wearing of hand gloves (99.1) and sterilising reusable devices $(95.2 \%)$ could control infectious diseases among health educators 
Difference on Influence of Level of Utilisation of Preventions Against COVID 19 Pandemic on Health educators' Job Commitment.

In an assessment, Reber, Wallin and Duhon (2013) discovered that utilisation of prevention significantly relate with control of infectious diseases among health workers in the state of New York. In an inquest, Tucker and Phillips (1999) found that females' health educators conform further with overall protections devices, than their male equal. In a related inquest, Murni, Duke, Kinney, Daley and Soenarto (2015) established that there was a reduction in level of utilisation of preventions by $22 \%$ following the achievement of a wide-ranging infectious diseases management. In a similar exploration, Okechukwu and Modteshi (2012) discovered that insufficient preventions equipment, excessive workload and time restraint were concern influencing negatively the utilisation of preventions against infectious diseases among health workers in Nigeria.

\section{Methodology}

The study employed descriptive survey design. A descriptive survey endeavor to explain uniqueness of issues or occurrences, views, thoughts and inclinations of persons of concern to the investigator. The population was 77 health educators in the four Federal and State Colleges of Education in Delta State. The researcher sampled the entire 77 teachers because of their fewness. The instrument for the investigation was titled "Influence of Covid 19 Pandemic on Health educators' Job Commitment Questionnaire (ICHLJCQ). The instrument was authenticated by expert's views. The researcher used split-half technique to examine the constancy of the instrument with pilot testing of 10 health educators in College of Education Igueben in Edo state public secondary that were not incorporated into the investigation. Pearson Product Moment Correlational Coefficient (r) was employed to ascertain the dependability of the instrument.

The worth of Pearson Product Moment Correlational Coefficient (r) for influence of COVID 19 pandemic was 0.73. The worth of Pearson Product Moment Correlational Coefficient ( $r$ ) for influence of utilization of prevention was 0.81. The worth of Pearson Product Moment Correlational Coefficient (r) for College support was 0.79. The worth of Pearson Product Moment Correlational Coefficient ( $r$ ) for level of awareness of utilisation of preventions was 0.83. The worth of Pearson Product Moment Correlational Coefficient (r) for the level of utilisation of preventions was 0.85. On the whole, the worth of Pearson Product Moment Correlational Coefficient (r) for COVID 19 pandemic was 0.77. Items on research question and null hypotheses 1 to 3 were scored with the four points scoring scale of Strongly Agree (4 points), Agree (3 points), Disagree ( 2 points) and Strongly Disagree (1 point). Research questions and null hypotheses 4 and 5 on the level of awareness of utilisation of preventions and the level of utilisation of preventions against COVID 19 pandemic were scored based on the 4 points scoring scale of Very High Extent ( 4 points), High Extent ( 3 points), Low Extent ( 2 points) and Very Low Extent (1 point). Out of entire copies of 77 instruments administered, 75 instruments were retrieved. Male health educators was 53 and female health educators 22 . The descriptive data of mean rating and standard deviation were employed to respond to the 5 research questions. Mean rating of 2.50 was assumed as the significant level of receipt as mean rating below 2.50 was discarded. $\mathrm{z}$ - test was employed to test the 5 null hypotheses formulated that direct the investigation at 0.05 levels of significance.

Presentation of Results.

Research Question 1.What is the influence of COVID 19 pandemic on health educators' job commitment in Federal and State owned Colleges of Education in Delta State? 
Table 1: Mean Rating of Respondents on Influence of COVID 19 Pandemic on Health educators, job commitment in federal and state owned colleges of education in Delta state

\begin{tabular}{|l|l|l|l|l|l|l|l|l|l|}
\hline & $\begin{array}{l}\text { Influence of COVID 19 } \\
\text { Pandemic on Health } \\
\text { S/N }\end{array}$ & \multicolumn{3}{|c|}{ Male Health educators } & \multicolumn{3}{|c|}{ Female Health educators } \\
\cline { 3 - 10 } \\
$\begin{array}{l}\text { educators Job Commitment } \\
\text { in Federal and State owned } \\
\text { Colleges of Education in Delta } \\
\text { state. }\end{array}$ & $\mathbf{N}$ & $\mathbf{X}$ & $\mathbf{S D}$ & Decision & $\mathbf{N}$ & $\overline{\mathbf{X}}$ & SD & Decision \\
\hline 1. & Poor quality teaching & 53 & 4.03 & 1.13 & + & 22 & 4.09 & 1.09 & + \\
\hline 2. & Delay in academic calendar & 53 & 3.97 & 0.79 & + & 22 & 4.01 & 0.75 & + \\
\hline 3. & $\begin{array}{l}\text { Inadequate coverage of course } \\
\text { outline. }\end{array}$ & 53 & 3.93 & 1.13 & + & 22 & 3.95 & 1.14 & + \\
\hline 4. & Demand for sick leave. & 53 & 3.89 & 0.75 & + & 22 & 3.91 & 0.83 & + \\
\hline 5. & Poor attendance to school. & 53 & 3.85 & 1.17 & + & 22 & 3.87 & 1.13 & + \\
\hline 6 & Inadequate attention to students & 53 & 3.81 & 0.81 & + & 22 & 3.83 & 0.79 & + \\
\hline 7 & Delay in graduation duration. & 53 & 3.77 & 1.19 & + & 22 & 3.79 & 1.05 & + \\
\hline 8 & Truancy among students. & 53 & 3.71 & 0.79 & + & 22 & 3.73 & 0.81 & + \\
\hline 9 & Strike Actions & 53 & 3.43 & 1.17 & + & 22 & 3.37 & 1.09 & + \\
\hline 10 & Job insecurity & 53 & 2.47 & 1.15 & - & 22 & 2.43 & 0.83 & - \\
\hline & Total & & 36.86 & 10.08 & & & 36.98 & 9.51 & \\
\hline & Grand Mean & & $\mathbf{3 . 6 9}$ & $\mathbf{1 . 0 1}$ & & & $\mathbf{3 . 7 0}$ & $\mathbf{0 . 9 5}$ & \\
\hline
\end{tabular}

$+=$ Agreed, $-=$ Disagreed

The data in table 1 shows that the mean rating from items 1 to 10 on influence of COVID 19 pandemic on health educators' job commitment in Federal and State owned Colleges of Education in Delta State. The respondents agreed on items 1 to 9 that poor quality teaching, delay in academic calendar, inadequate coverage of course outline, demand for sick leave, poor attendance to school, inadequate attention to students, delay in graduation duration, truancy among students and strike actions. With the data in table 1 and the mean rating from items 1 to 10, the followings were discovered. The mean rating for male health educators was 3.69 and standard deviation of 1.01 while the mean rating for female health teachers was 3.70 and standard deviation of 0.95 . Using the standard level of acceptance for the investigation as 2.50 , the ratings of male and female health educators were higher than the criterion level of receipt. This implied that influence of COVID 19 pandemic on health educators' job commitment in Federal and State owned Colleges of Education in Delta State was high as the ratings were high.

Research Question 2: What is the influence of utilisation of prevention against COVID 19 pandemic and health teachers ' job commitment in Federal and State owned Colleges of Education in Delta State?

Table 2: Mean Rating of Respondents on the influence of Utilisation of Prevention against COVID 19 Pandemic and Health teachers , Job Commitment in Federal and State owned Colleges of Education in Delta State

\begin{tabular}{|l|l|l|l|l|l|l|r|r|r|}
\hline S/N & $\begin{array}{l}\text { Influence of Utilisation of Prevention } \\
\text { against COVID 19 Pandemic on Health } \\
\text { educators Job Commitment in Federal } \\
\text { and State owned Colleges of Education in } \\
\text { Delta State }\end{array}$ & $\mathbf{N}$ & $\mathbf{X}$ & SD & Decision & $\mathbf{N}$ & $\overline{\mathbf{X}}$ & SD & Decision \\
\hline 1. & $\begin{array}{l}\text { I am committed to my job owing to } \\
\text { continuous use of preventions against } \\
\text { COVID 19 pandemic. }\end{array}$ & 53 & 2.47 & 0.81 & - & 22 & 2.45 & 0.79 & - \\
\hline 2. & $\begin{array}{l}\text { I am committed to my job owing to the use } \\
\text { procedure for evaluation of possible danger } \\
\text { against COVID 2019 pandemic. }\end{array}$ & 53 & 2.45 & 1.13 & - & 22 & 2.41 & 1.13 & - \\
\hline 3. & $\begin{array}{l}\text { I am committed to my job because I am } \\
\text { against crowd gatherings in the present } \\
\text { COVID-19 eruption }\end{array}$ & 53 & 2.41 & 0.87 & - & 22 & 2.39 & 0.76 & - \\
\hline 4. & $\begin{array}{l}\text { I am committed to my job due to } \\
\text { my use of approaches of preventions } \\
\text { against COVID 19 pandemic }\end{array}$ & 53 & 2.39 & 1.15 & - & 22 & 2.35 & 1.05 & - \\
\hline 5 & $\begin{array}{l}\text { I am committed to my job because I } \\
\text { guarantee fair utilization of special } \\
\text { protective instrument against COVID-19 }\end{array}$ & 53 & 2.35 & 0.77 & - & 22 & 2.33 & 0.77 \\
\hline
\end{tabular}




\begin{tabular}{|c|c|c|c|c|c|c|c|c|c|}
\hline \multirow[b]{2}{*}{$\mathbf{S} / \mathbf{N}$} & \multirow{2}{*}{$\begin{array}{l}\text { Influence of Utilisation of Prevention } \\
\text { against COVID } 19 \text { Pandemic on Health } \\
\text { educators Job Commitment in Federal } \\
\text { and State owned Colleges of Education in } \\
\text { Delta State }\end{array}$} & \multicolumn{4}{|c|}{ Male Health educators } & \multicolumn{4}{|c|}{ Female Health educators } \\
\hline & & $\mathbf{N}$ & $\overline{\mathbf{X}}$ & SD & Decision & $\mathbf{N}$ & $\overline{\mathbf{x}}$ & SD & Decision \\
\hline & virus & & & & & & & & \\
\hline 6 & $\begin{array}{l}\text { I am committed to my job because I engage } \\
\text { in online lessons for community health } \\
\text { awareness on COVID-19 virus. }\end{array}$ & 53 & 2.33 & 1.03 & - & 22 & 2.31 & 1.15 & - \\
\hline 7 & $\begin{array}{l}\text { I am committed to my job because I use } \\
\text { handbook for the management of COVID } \\
19 \text { pandemic. }\end{array}$ & 53 & 2.29 & 0.85 & - & 22 & 2.27 & 1.13 & - \\
\hline 8 & $\begin{array}{l}\text { I am committed to my job because I use } \\
\text { face verification of COVID- } 19 \text { pandemic. }\end{array}$ & 53 & 2.23 & 1.16 & - & 22 & 2.23 & 1.09 & - \\
\hline 9 & $\begin{array}{l}\text { I am committed to my job because I use } \\
\text { advice on the use of masks in the } \\
\text { community against COVID } 19 \text { pandemic. }\end{array}$ & 53 & 2.19 & 0.75 & - & 22 & 2.17 & 0.81 & - \\
\hline 10 & $\begin{array}{l}\text { I am committed to my job because of my } \\
\text { utilization of dependable test tool for testing } \\
\text { COVID- } 19 \text { virus. }\end{array}$ & 53 & 2.17 & 1.09 & - & 22 & 2.13 & 1.19 & - \\
\hline 11 & $\begin{array}{l}\text { I am committed to my job because of my } \\
\text { utilization of home evaluation technique to } \\
\text { assess possible COVID-19 issues. }\end{array}$ & & 2.15 & 1.03 & - & & 2.11 & 0.73 & - \\
\hline & Total & & 25.4 & 10.6 & & & 25.1 & 10.6 & \\
\hline & Grand Mean & & 2.32 & 0.97 & & & 2.29 & 0.96 & \\
\hline
\end{tabular}

$+=$ Agreed, - = Disagreed

The data in table 2 shows that the mean rating from items 1 to 11 on the influence of utilisation of prevention against COVID 19 pandemic and health teachers 'job commitment in Federal and State owned Colleges of Education in Delta State. The respondents disagreed on all the items.

With the data in table 2 and the mean rating from items 1 to 11 , the followings were observed. The mean rating for male health educators was 2.32 and standard deviation of 0.97 while the mean rating for female health educators was 2.29 and standard deviation of 0.96 . With the level of receipt for the investigationas 2.50 , the ratings of male and female health educators were lower than the criterion level of receipt. This showed that the influence of utilisation of prevention against COVID 19 pandemic and health teachers ' job commitment in Federal and State owned Colleges of Education in Delta State was low as the ratings were low

Research Question 3: What is the influence of College support on the utilisation of prevention against COVID 19 pandemic and health educator's job commitment in Federal and State owned Colleges of Education in Delta State? 
Table 3: Mean Rating of Respondents on the Influence of College Support on the Utilisation of Prevention Against COVID 19 Pandemic on Health educators Job Commitment in Federal and State owned Colleges of Education in Delta State

\begin{tabular}{|c|c|c|c|c|c|c|c|c|c|}
\hline \multirow{2}{*}{$\mathbf{S} / \mathbf{N}$} & \multirow[b]{2}{*}{$\begin{array}{l}\text { Influence of College support on the } \\
\text { Utilisation of Prevention against COVID } \\
19 \text { Pandemic and Health } \\
\text { teachers Job Commitment in Federal } \\
\text { and State owned Colleges } \\
\text { Education in Delta State }\end{array}$} & \multicolumn{4}{|c|}{ Male Health educators } & \multicolumn{4}{|c|}{ Female Health educators } \\
\hline & & $\mathbf{N}$ & $\mathbf{X}^{-}$ & SD & Decision & $\mathbf{N}$ & $\mathbf{x}^{-}$ & SD & Decision \\
\hline 1. & $\begin{array}{l}\text { My college has a duty to progress health } \\
\text { educators awareness levels on COVID } 19\end{array}$ & 53 & 4.11 & 0.87 & + & 22 & 3.97 & 1.02 & + \\
\hline 2. & $\begin{array}{l}\text { My college provide support } \\
\text { in the implementation of needed } \\
\text { against COVID } 19\end{array}$ & 53 & 2.47 & 1.05 & - & 22 & 2.43 & 0.79 & - \\
\hline 3. & $\begin{array}{l}\text { My college encourages health educators to } \\
\text { use online related updates on COVID-19- } \\
\text { posted by authorized health authorities }\end{array}$ & 53 & 2.43 & 1.09 & - & 22 & 2.41 & 0.91 & - \\
\hline 4. & $\begin{array}{l}\text { My college supports the use of social media } \\
\text { as a basis of data on COVID } 19 \text { pandemic. }\end{array}$ & 53 & 2.37 & 0.73 & - & 22 & 2.33 & 1.15 & - \\
\hline 5 & $\begin{array}{l}\text { My college use suggested procedures to } \\
\text { reduce the spread of COVID } 19 \text { virus. }\end{array}$ & 53 & 2.27 & 1.13 & - & 22 & 2.31 & 1.11 & - \\
\hline 6 & $\begin{array}{l}\text { My college respond to } \\
\text { challenges at all times }\end{array}$ & 53 & 2.22 & 0.75 & - & 22 & 2.26 & 0.79 & - \\
\hline 7 & $\begin{array}{l}\text { My college encourages enlightenment } \\
\text { campaigns against COVID } 19 \text { for health } \\
\text { educators. }\end{array}$ & 53 & 2.15 & 1.18 & - & 22 & 2.18 & 1.09 & - \\
\hline 8 & $\begin{array}{l}\text { My college provides resources to progress } \\
\text { health educators awareness of COVID-19 }\end{array}$ & 53 & 2.11 & 0.73 & - & 22 & 2.16 & 0.81 & - \\
\hline 9 & $\begin{array}{l}\text { My college provides adequate personal } \\
\text { protective tools needed to lessen COVID-19 } \\
\text { pandemic. }\end{array}$ & 53 & 2.09 & 1.05 & - & 22 & 2.12 & 1.13 & - \\
\hline 10 & $\begin{array}{l}\text { My college discourages social gatherings of } \\
\text { further than } 10 \text { populace. }\end{array}$ & 53 & 2.03 & 0.81 & - & 22 & 2.07 & 0.79 & - \\
\hline & Total & & 22.2 & 6.38 & & & 22.21 & 9.59 & \\
\hline & Grand Mean & & 2.43 & 0.64 & & & 2.42 & 0.96 & \\
\hline
\end{tabular}

$$
+=\text { Agreed, }-=\text { Disagreed }
$$

The data in table 3 shows that the mean rating from items 1 to 10 on the influence of College support on the utilisation of prevention against COVID 19 pandemic and health educator's job commitment in Federal and State owned Colleges of Education in Delta State. The respondents agreed on only item 1 that their college has a duty to progress health educator's awareness levels on COVID 19.

With the data in table 3 and the mean rating from items 1 to 10 , the followings were observed. The mean rating for male health educators was 2.43 and standard deviation of 0.64 while the mean rating for female health educators was 2.42 and standard deviation of 0.96 . With the level of receipt for the investigation as 2.50 , the ratings of male and female health educators were higher than the criterion level of acceptance. This showed that the influence of College support on the utilisation of prevention against COVID 19 pandemic and health educator's job commitment in Federal and State owned Colleges of Education in Delta State was low as the ratings was low.

Research Question 4: What is the level of awareness of utilisation of preventions against COVID 19 pandemic on health educators , job commitment in federal and state owned colleges of education in Delta state? 
Table 4: Mean Rating of Respondents on the Level of Awareness of Utilisation of Preventions Against COVID 19 Pandemic on Health educators' job commitment in federal and state owned colleges of education in Delta state

\begin{tabular}{|c|c|c|c|c|c|c|c|c|c|}
\hline \multirow{2}{*}{$\mathrm{S} / \mathrm{N}$} & \multirow{2}{*}{$\begin{array}{l}\text { Level of Awareness of Utilisation of } \\
\text { Preventions Against COVID } 19 \text { Pandemic } \\
\text { on Health educators job commitment } \\
\text { in federal and state owned colleges of } \\
\text { education in Delta state }\end{array}$} & \multicolumn{4}{|c|}{ Male Health educators } & \multicolumn{4}{|c|}{ Female Health educators } \\
\hline & & $\mathbf{N}$ & $\overline{\mathbf{X}}$ & SD & Decision & $\mathbf{N}$ & $\bar{X}$ & SD & Decision \\
\hline 1. & $\begin{array}{l}\text { I am aware that COVID19 epidemic is } \\
\text { occurring worldwide in } 2020\end{array}$ & 53 & 4.03 & 1.09 & + & 22 & 3.98 & 0.85 & + \\
\hline 2. & $\begin{array}{l}\text { I have adequate awareness on COVID-19 } \\
\text { pandemic }\end{array}$ & 53 & 3.97 & 0.77 & + & 22 & 3.93 & 1.13 & + \\
\hline 3. & $\begin{array}{l}\text { I am familiar with the mode of spread of } \\
\text { COVID-19 pandemic. }\end{array}$ & 53 & 3.89 & 1.08 & + & 22 & 3.91 & 0.71 & + \\
\hline 4. & $\begin{array}{l}\text { I am aware that COVID-19 is spread by } \\
\text { shut contact with the contaminated person }\end{array}$ & 53 & 3.85 & 0.81 & + & 22 & 3.87 & 1.13 & + \\
\hline 5 & $\begin{array}{l}\text { I have adequate awareness of the isolation } \\
\text { period of COVID- } 19 \text { pandemic. }\end{array}$ & 53 & 3.82 & 1.13 & + & 22 & 3.85 & 1.11 & + \\
\hline 6 & $\begin{array}{l}\text { I am aware that patients with basic constant } \\
\text { illnesses are at a elevated danger of } \\
\text { contamination. }\end{array}$ & 53 & 3.76 & 1.05 & + & 22 & 3.83 & 0.79 & + \\
\hline 7 & $\begin{array}{l}\text { I have helpful approach about the danger of } \\
\text { COVID-19 pandemic on me. }\end{array}$ & 53 & 3.73 & 0.83 & + & 22 & 3.69 & 1.15 & + \\
\hline 8 & $\begin{array}{l}\text { I have adequate awareness of how members } \\
\text { of my family can be affected by COVID-19 } \\
\text { pandemic. }\end{array}$ & 53 & 3.68 & 1.07 & + & 22 & 3.62 & 0.79 & + \\
\hline 9 & I am aware that the isolation time is 2 weeks & 53 & 3.65 & 1.04 & + & 22 & 3.59 & 1.13 & + \\
\hline 10 & $\begin{array}{l}\text { I am aware that patients with basic constant } \\
\text { ailments are at an elevated threat of death }\end{array}$ & 53 & 3.57 & 0.77 & + & 22 & 3.54 & 1.06 & + \\
\hline 11 & $\begin{array}{l}\text { I require to be careful with patients with } \\
\text { constant ailments as they are more prone to } \\
\text { die from the infirmity }\end{array}$ & 53 & 3.49 & 1.17 & + & 22 & 3.45 & 0.79 & + \\
\hline & Total & & 41.4 & 7.87 & & & 41.2 & 10.6 & \\
\hline & Grand Mean & & 3.77 & 0.72 & & & 3.76 & 0.97 & \\
\hline
\end{tabular}

$+=$ High Extent, - = Low Extent

The data in table 4 shows that the mean rating from items 1 to 11 was on the level of awareness of utilisation of preventions against COVID 19 pandemic on health educators ' job commitment in federal and state owned colleges of education in Delta state. The respondents agreed on all the items that they were aware that COVID19 epidemic is occurring worldwide in 2020, they have adequate awareness on COVID-19 pandemic, they are familiar with the mode of spread of COVID-19 pandemic, they are aware that COVID-19 is spread by shut contact with the contaminated person, they have adequate awareness of the isolation period of COVID-19 pandemic, they are aware that patients with basic constant illnesses are at a elevated danger of contamination, they have helpful approach about the danger of COVID-19 pandemic on me, they have adequate awareness of how members of my family can be affected by COVID-19 pandemic, they are aware that the isolation time is 2 weeks, they are aware that patients with basic constant ailments are at an elevated threat of death and they require to be careful with patients with constant ailments as they are more prone to die from the infirmity.

With the data in table 4 and the mean rating from items 1 to 11 , the followings were detected. The mean rating for male health educators was 3.77 and standard deviation of 0.72 while the mean rating for female health educators was 3.76 and standard deviation of 0.97 . With the level of receipt for the investigation as 2.50 , the ratings of Male and female health educators were more than the standard level of receipt. This showed that the level of awareness of utilisation of preventions against COVID 19 pandemic on health educators ' job commitment in federal and state owned colleges of education in Delta state were high as the ratings were high.

Research Question 5: What is the level of utilisation of preventions against COVID 19 pandemic on health educators' job commitment in federal and state owned colleges of education in Delta state. 
Table 5: Mean Rating of Respondents on the Level of Utilisation of Preventions Against COVID 19 Pandemic on Health educators, Job Commitment in Federal and State owned Colleges of Education in Delta state

\begin{tabular}{|c|c|c|c|c|c|c|c|c|c|}
\hline \multirow[b]{2}{*}{$\mathbf{S} / \mathbf{N}$} & \multirow{2}{*}{$\begin{array}{l}\text { Level of Utilisation of Preventions } \\
\text { Against Covid } 19 \text { Pandemic on Health } \\
\text { educators Job Commitment in Federal } \\
\text { and State owned Colleges of Education in } \\
\text { Delta State. }\end{array}$} & \multicolumn{4}{|c|}{ Male Health educators } & \multicolumn{4}{|c|}{ Female Health educators } \\
\hline & & $\mathbf{N}$ & $\mathbf{X}^{-}$ & SD & Decision & $\mathbf{N}$ & $\mathbf{x}^{-}$ & SD & Decision \\
\hline 1 & $\begin{array}{l}\text { I constantly wear face mask to shun COVID } \\
19 \text { pandemic. }\end{array}$ & 53 & 2.43 & 1.07 & - & 22 & 2.41 & 0.81 & - \\
\hline 2 & $\begin{array}{l}\text { I constantly wash my hands with soaps and } \\
\text { water to shun COVID } 19 \text { pandemic. }\end{array}$ & 53 & 2.37 & 0.75 & - & 22 & 2.37 & 1.06 & - \\
\hline 3 & $\begin{array}{l}\text { I constantly stay at least } 2 \text { meters distance } \\
\text { to shun COVID } 19 \text { pandemic }\end{array}$ & 53 & 2.35 & 1.08 & - & 22 & 2.31 & 0.75 & - \\
\hline 4. & $\begin{array}{l}\text { I constantly wear goggles to COVID } 19 \\
\text { pandemic. }\end{array}$ & 53 & 2.33 & 0.83 & - & 22 & 2.27 & 1.13 & - \\
\hline 5 & $\begin{array}{l}\text { I constantly wear gown or apron to shun } \\
\text { COVID } 19 \text { pandemic. }\end{array}$ & 53 & 2.28 & 1.13 & - & 22 & 2.23 & 1.15 & - \\
\hline 6 & $\begin{array}{l}\text { I constantly wear hand gloves to shun } \\
\text { COVID } 19 \text { pandemic. }\end{array}$ & 53 & 2.25 & 1.09 & - & 22 & 2.19 & 0.79 & - \\
\hline 7 & $\begin{array}{l}\text { I constantly change hand gloves to shun } \\
\text { COVID } 19 \text { pandemic. }\end{array}$ & 53 & 2.21 & 0.75 & - & 22 & 2.13 & 1.17 & - \\
\hline 8 & $\begin{array}{l}\text { I constantly wash my skin surfaces to shun } \\
\text { COVID } 19 \text { pandemic.. }\end{array}$ & 53 & 2.18 & 1.11 & - & 22 & 2.07 & 0.83 & - \\
\hline 9 & $\begin{array}{l}\text { I constantly check my body temperature } \\
\text { with temperature check to shun COVID } 19 \\
\text { pandemic. }\end{array}$ & 53 & 2.11 & 0.79 & - & 22 & 2.03 & 1.14 & - \\
\hline 10 & $\begin{array}{l}\text { I constantly protect my eyes with eye shield } \\
\text { to shun COVID } 19 \text { pandemic. }\end{array}$ & 53 & 2.07 & 1.13 & - & 22 & 2.01 & 0.69 & - \\
\hline & Total & & 22.5 & 8.78 & & & 22.0 & 9.52 & \\
\hline & Grand Mean & & 2.26 & 0.88 & & & 2.21 & 0.95 & \\
\hline
\end{tabular}

$+=$ High Extent, - = Low Extent

The data in table 5 shows that the mean rating from items 1 to 10 on the level of utilisation of preventions against COVID 19 pandemic on health educators ' job commitment in federal and state owned colleges of education in Delta state. The respondents disagreed on all the 10 items.

With the data in table 5 and the mean rating from items 1 to 10 , the subsequent were detected. The mean rating for male health educators was 2.26 and standard deviation of 0.88 while the mean rating for female health teachers was 2.21 and standard deviation of 0.95 . With the level of receipt for the investigation as 2.50 , the ratings of male and female health teachers were lesser than the standard level of receipt. This showed that the level of utilisation of preventions against COVID 19 pandemic on health educators , job commitment in federal and state owned colleges of education in Delta state was low as the ratings was low.

Hypothesis 1: There is no significant difference on influence of COVID 19 pandemic on health educators , job commitment in Federal and State owned Colleges of Education in Delta State.

Table 6: $z$ test analysis of the Significant Difference on Influence of COVID 19 Pandemic on Health educators ' Job Commitment in Federal and State owned Colleges of Education in Delta State.

\begin{tabular}{|c|c|c|c|c|c|c|c|c|c|}
\hline States & & $\mathbf{N}$ & $\frac{x}{-}$ & SD & Df & Level of Significance & $\begin{array}{l}\text { Calculated } \\
\text { z-Value }\end{array}$ & $\begin{array}{l}\text { Critical } \\
\text { z-Value }\end{array}$ & Decisions \\
\hline Male Health educators & 53 & 34.06 & & 20.25 & & & & & Not Significant \\
\hline Female Health educators & 22 & 33.21 & & 17.64 & 73 & 0.05 & 1.35 & 1.96 & Accept Ho4 \\
\hline
\end{tabular}

Tables 6 indicated that calculated $z$ value of 1.35 was lesser than the critical $z$ value of 1.96 . Thus, the null hypothesis was acknowledged. This indicated that there was no significant difference on influence of COVID 19 pandemic on health educators ' job commitment in Federal and State owned Colleges of Education in Delta State.

Hypothesis 2: There is no significant difference on influence of utilisation of prevention against COVID 19 pandemic on health teachers ' job commitment in Federal and State owned Colleges of Education in Delta State. 
Table 7: $\mathrm{z}$ test analysis of the Significant Difference on Influence of Utilisation of Prevention against COVID 19 Pandemic on Health Teachers 'Job Commitment in Federal and State owned Colleges of Education in Delta State.

\begin{tabular}{|c|c|c|c|c|c|c|c|c|}
\hline States & & $\begin{array}{l}\mathbf{X} \\
-\end{array}$ & SD & Df & Level of Significance & $\begin{array}{l}\text { Calculated } \\
\text { z-Value }\end{array}$ & $\begin{array}{l}\text { Critical } \\
\text { z-Value }\end{array}$ & Decisions \\
\hline Male Health educators & 53 & 32.38 & 13.03 & & & & & Not Significant \\
\hline Female Health educators & 22 & 34.35 & 35.64 & 73 & 0.05 & -2.81 & 1.96 & Accept Ho4 \\
\hline
\end{tabular}

Tables 7 indicated that calculated $z$ value of ${ }^{-2.81}$ was lesser than the critical $z$ value of 1.96 . Thus, the null hypothesis was acknowledged. This indicated that there was no significant difference on influence of utilisation of prevention against COVID 19 pandemic on health teachers ' job commitment in Federal and State owned Colleges of Education in Delta State.

Hypothesis 3: There is no significant difference on influence of College support on the utilisation of prevention against COVID 19 pandemic on health teachers job commitment in Federal and State owned Colleges of Education in Delta State.

Table 8: $\mathrm{z}$ test analysis of the Significant Difference on Influence of College support on the utilisation of prevention against COVID 19 pandemic on health teachers job commitment in Federal and State owned Colleges of Education in Delta State.

\begin{tabular}{|c|c|c|c|c|c|c|c|c|}
\hline States & $\mathbf{N}$ & X & SD & Df & Level of Significance & $\begin{array}{l}\text { Calculated } \\
\text { z-Value }\end{array}$ & $\begin{array}{l}\text { Critical } \\
\text { z-Value }\end{array}$ & Decisions \\
\hline Male Health educators & 53 & 46.43 & 11.25 & & & & & Not Significant \\
\hline Female Health educators & 22 & 56.74 & 9.88 & 73 & 0.05 & -1.81 & 1.96 & Accept Ho4 \\
\hline
\end{tabular}

Tables 8 indicated that calculated $\mathrm{z}$ value of -1.81 was lesser than the critical $\mathrm{z}$ value of 1.96 . Thus, the null hypothesis was acknowledged. This indicated that there was no significant difference on influence of College support on the utilisation of prevention against COVID 19 pandemic on health teachers job commitment in Federal and State owned Colleges of Education in Delta State.

Hypothesis 4: There is no significant difference on influence of the level of awareness of utilisation of preventions against COVID 19 pandemic on health educators 'job commitment in federal and state owned colleges of education in Delta state .

Table 9: $\mathrm{z}$ test analysis of the Significant Difference on Influence of the level of awareness of utilisation of preventions against COVID 19 pandemic on health educators' job commitment in federal and state owned colleges of education in Delta state.

\begin{tabular}{|c|c|c|c|c|c|c|c|c|}
\hline States & $\mathbf{N}$ & $\begin{array}{l}\mathbf{X} \\
-\end{array}$ & SD & Df & Level of Significance & $\begin{array}{l}\text { Calculated } \\
\text { z-Value }\end{array}$ & $\begin{array}{l}\text { Critical } \\
\text { z-Value }\end{array}$ & Decisions \\
\hline Male Health educators & 53 & 56.74 & 9.88 & & & & & Not Significant \\
\hline Female Health educators & 22 & 46.43 & 11.25 & 73 & 0.05 & 1.14 & 1.96 & Accept Ho4 \\
\hline
\end{tabular}

Tables 9 indicated that calculated $z$ value of 1.14 was lesser than the critical $z$ value of 1.96 . Thus, the null hypothesis was acknowledged. This indicated that there was no significant difference on influence of the level of awareness of utilisation of preventions against COVID 19 pandemic on health educators ' job commitment in federal and state owned colleges of education in Delta state.

Hypothesis 5: There is no significant difference on influence of level of utilisation of preventions against COVID 19 pandemic on health educators' job commitment in federal and state owned colleges of education in Delta state .

Table 10: $\mathrm{z}$ test analysis of the Significant Difference on Influence of Level of Utilisation of Preventions against COVID 19 Pandemic on Health educators 'Job Commitment in Federal and State owned Colleges of Education in Delta state.

\begin{tabular}{|c|c|c|c|c|c|c|c|c|}
\hline States & $\mathbf{N}$ & - & SD & Df & Level of Significance & $\begin{array}{l}\text { Calculated } \\
\text { z-Value }\end{array}$ & $\begin{array}{l}\text { Critical } \\
\text { z-Value }\end{array}$ & Decisions \\
\hline Male Health educators & 53 & 56.74 & 9.88 & & & & & Not Significant \\
\hline Female Health educators & 22 & 46.43 & 11.25 & 73 & 0.05 & 0.18 & 1.96 & Accept $\mathrm{Ho} 4$ \\
\hline
\end{tabular}

Tables 10 indicated that calculated $\mathrm{z}$ value of 0.18 was lesser than the critical $\mathrm{z}$ value of 1.96 . Thus, the null hypothesis was acknowledged. This indicated that there was no significant difference on influence of level of utilisation of preventions against COVID 19 pandemic on health educators ' job commitment in federal and state owned colleges of education in Delta state . 
Findings:

1 Influence of COVID 19 pandemic on health educators' job commitment in Federal and State owned Colleges of Education in Delta State was high as the ratings were high.

2 Influence of utilisation of prevention against COVID 19 pandemic and health teachers' job commitment in Federal and State owned Colleges of Education in Delta State was low as the ratings were low .

3 Influence of College support on the utilisation of prevention against COVID 19 pandemic and health educator's job commitment in Federal and State owned Colleges of Education in Delta State was low as the ratings was low.

4 The level of awareness of utilisation of preventions against COVID 19 pandemic on health teachers ' job commitment in federal and state owned colleges of education in Delta state were high as the ratings were high.

5 The level of utilisation of preventions against COVID 19 pandemic on health educators ' job commitment in federal and state owned colleges of education in Delta state was low as the ratings was low.

6 There was no significant difference on influence of COVID 19 pandemic, utilisation of prevention against COVID 19 pandemic, College support, level of awareness and level of utilisation of preventions against COVID 19 pandemic on health educators ' job commitment in federal and state owned colleges of education in Delta state at 0.05 level of significance..

\section{Conclusion.}

1 Influence of COVID 19 pandemic on health educators' job commitment in Federal and State owned Colleges of Education in Delta State was high

2 Influence of utilisation of prevention against COVID 19 pandemic and health teachers , job commitment in Federal and State owned Colleges of Education in Delta State was low

3 Influence of College support on the utilisation of prevention against COVID 19 pandemic and health educator's job commitment in Federal and State owned Colleges of Education in Delta State was low.

4 The level of awareness of utilisation of preventions against COVID 19 pandemic on health teachers ' job commitment in federal and state owned colleges of education in Delta state were high .

5 The level of utilisation of preventions against COVID 19 pandemic on health educators 'job commitment in federal and state owned colleges of education in Delta state was low .

6 There was no significant difference on influence of COVID 19 pandemic, utilisation of prevention against COVID 19 pandemic, College support the level of awareness of utilisation of preventions against COVID 19 pandemic and level of utilisation of preventions against COVID 19 pandemic on health educators ' job commitment in federal and state owned colleges of education in Delta state .

\section{Recommendations. The subsequent recommendations were made:}

1 Commitment should be shown on prevention of COVID 19 pandemic by health educators in Federal and State owned Colleges of Education in Delta State

2 The Colleges of education administrators should support health educators to enhance their utilisation of prevention against COVID 19 pandemic to enhance their job commitment in Federal and State owned Colleges of Education in Delta State.

3 The colleges of education administrators should as well roll out comprehensive educational programmes for the control of the virus in the colleges.

4 The level of awareness of utilisation of preventions against COVID 19 pandemic should be enhanced among health teachers in federal and state owned colleges of education in Delta state .

5 The level of utilisation of preventions against COVID 19 pandemic should be enhanced among health teachers in federal and state owned colleges of education in Delta state .

6 Guidance and counseling department should be created in the colleges for enlightenment among staff and students against COVID 19 pandemic.

\section{References}

Abdullah A \& Allen C (2016) . Knowledge, attitudes and behaviours of healthcare workers in the Kingdom of Saudi Arabia to MERS corona virus and other emerging infectious diseases. International Journal of Environmental Research and Public Health ,13, 1214.

Adebayo, C (2013) How safe is our Nigerian campuses. Quadlife. Vanguard Newspaper, Thursday, January 10,27 .

African Centre for Diseases Control (2020) Covid-19 Scientific and Public Health Policy Update - (March 17, 2020). 
American Center for Disease Control (2020) Morbidity and mortality weekly report. Guideline for hand hygiene in health- care settings recommendations of the healthcare infection control practices centers for disease control and prevention. T. M.

Bamigboye, A. P, Adesanya, A. T (2006) Knowledge and practice of universal precautions amongst qualifying medical and nursing health educators : A case of Obafemi Awolowo University Teaching Hospitals Complex, Ile-Ife. Journal of Medical Science, 1, 112-6.

Bhagavathula, A.S ; Aldhaleei, W.A ; Rahmani , J ; Mahabadi, M.M \& Bandari, D.K (2020) Knowledge and perceptions of Covid-19 among health educators : cross-sectional study. Institute of Public Health, Colleges of Medicine and Health Sciences, United Arab Emirates University.

Boe, E. E., Cook, L., \& Sunderland, R. (2008). Teacher turnover: Examining exit attrition, teaching area transfer, and school migration. Council for Exceptional Children, 75(1), 7-31.

Burleson, S. E \& Thoron. A. C. (2014). Maslow's hierarchy of needs and its relation to learning and achievement Agricultural Education and Communication Department, UF/IFAS Extension. http://edis.ifas.ufl.edu

Caudran, S. (2016). Employee commitment integrate workplace paradox of workforce magazine.

Centers for Disease Control and Prevention (2020). Update and interim guidelines on outbreak of 2019 Novel coronavirus (2019-nCoV) URL: https://emergency.cdc.gov/han/han00427.asp [accessed 2020-02-12].

Cole, M.S \& Bruch H. (2016). Organisational identity strength, identification, and commitment and their relationships to turnover intention: Does organisational hierarchy matter? St Gallen, Switzerland Journal of Organisational Behaviour, 27, 585-605.

Dania, P.O. \& Eboh, R.N. (2013) Social studies education for national security. Research Journal of Delta State University. Research in Education 19(1), December. 64.

Egwuenu, S.E.O \& Okanlawon, F.A (2014) Infection control: health educators ' knowledge and practice of universal precaution in Delta State, Nigeria. African Journal of Medicine, June, 3(2), 127- 34.

Eisenberger, R., Fasolo, P \& Davis-LaMastro,V. (2010). Perceived organisational support and employee diligence, commitment, and innovation. Journal of Applied Psychology, 75, 51-59 .

Eisenberger, R., Huntington, R., Hutchison, S \& Sowa, D. (2016). Perceived organisational support .Journal of Applied Psychology, 71 500-507.

Federal Republic of Nigeria (2014) National policy on education : Abuja: NERDC.

Gadzama, G.B; Bawa, S.B; Ajinoma, Z; Saidu, M.M \& Umar, A. S (2014). Injection protection practices in a main referral hospital in Northeastern Nigeria. Journal of Clinical Practice, 17, 134-9.

Ganagana, D.P. \& Splent-Martina, U. (2017) Enhancing the learning and teaching process in tertiary education through balance of student staff relationship. Email

Giao, H ; Thi, N ; Han, N : Khanh3, T.V ; Ngan, V.K , Tam, V.V \& An, P.L (2020) Knowledge and attitude toward COVID-19 among healthcare workers at District 2 Hospital, Ho Chi Minh City. Asian Pacific Journal of Tropical Medicine 2020; 13 .

Greenlee, B., \& Brown, J. J. (2009). Retaining teachers in challenging schools. Education, 130(1), 96-109.

Hanmore, E; Maclaine, G; Garin, F ; Alonso, A; Leroy, N \& Ruff, L (2013). Economic benefits of protectionengineered sharp devices in Belgium-a budget impact theory. BMC Health Services Resources, 13, 489.

Hawkins, W, D. (2018). Predictors of Affective Organisational Commitment among High School Male health educators. Virginia, Blacksburg.

Ingersoll, R., \& May, H. (2011). Recruitment, retention, and the minority teacher shortage. CPRE Research Report, 1- 63.

Ingersoll, R., Merrill, L., \& May, H. (2014). What are the effects of teacher education and preparation on beginning teacher attrition? CPRE Research Reports, July 2014.

Iliyasu, G; Dayyab, F.M ; Habib,Z.G ; Tiamiyu, A.B ; Abubakar, S ; Mijinyawa, S.M \& Habib, A.G (2020) Infection control in healthcare facilities. Journal ofMedical Science, 1, 109-116.

Imogie ,A. O (2019)Towards a better understanding of health education. Benin Journal of Educational Studies 1 (2),66- 69 .

Jones, W.B ; O’Connor , F.G ; Deuster,P ; Peck , J ; Shake, C \& Frost, S.S (2010) Why total force fitness. Military Medicine. .

Kampf, G, Löffler H \& Gastmeier P (2009) Hand hygiene for the prevention of nosocomial infections. Dutch Arztebl International, 106, 649-56.

Lee, S. S; Park, S.J; Chung, M.J; Lee, J.H; Kang, H. J \& Lee J.A, et al (2014). Improved hand hygiene compliance is associated with the change of perception toward hand hygiene among medical personnel. Infect Chemother, 46, 165-71.

Margolis, J. (2008). What will keep today's teachers teaching? Looking for a hook as a new career cycle emerges. Teachers College Record, 110(1), 160-194.

Margolis, J., \& Deuel, A. (2009). Teacher leaders in action: Motivation, morality and money. Leadership and 
Policy in Schools, 8, 264-286.

Marzano, R. J., Waters, T \& McNulty, B. A. (2005). School leadership that works:From research to results. Alexandria, VA: Association for Supervision and Curriculum Development.

Maslow, A. H. (1943). A theory of human motivation. Psychological Review, 50(4), 370.

Mathieu, J.E \& Zajac, D.M. (2010) A review and meta-analysis of the antecedents, correlates, and consequences of organisational commitment . Psychological Bulletin,108,(2). 171-194.

McElroy, J. .E \& Allen, J. (2013). Organisational Commitment s: Evidence of Career Effects, Journal of Business Research 26( 6).

Mee, M\& Haverback, H. R. (2014). Commitment, preparation, and early career frustrations: Examining future attrition of middle school teachers. American Secondary Education, 42(3), 39-51.

Meyer J. P., Paunonen S. V., Gellatly I. R., Goffin R. D \& Jackson D. N. (2019) Organisational commitment and job commitment : It's the nature of the commitment that counts. Journal of Applied Psychology, 74, 152156

Meyer, J. P \& Allen, N. J. (2011). A three-component conceptualisation of organisational commitment . Human Resources Management Review, 1, 61-89. 317

Meyer, J. P \& Allen, N.J. (2017).Commitment in the workplace; Theory research and application; Thousand Oaks, CA; Sage.

Mottaz, C. (2018). Determinants of organisational commitment . The Tavistock Institute. Sage Journal 41( 8).

Mullins, L. J. (2017). Management van gedrag: Individual, team in organisation. Amsterdam. Person Education.

Murni, I. K; Duke T, Kinney S, Daley AJ, Soenarto Y. Reducing hospital-acquired infections and improving the rational utilisation of antibiotics in a developing country: An effectiveness study. Archival Diseases of Children, 100, 54-59.

Nabofa, O.E \& Dada , O.B (2013) Nigeria peoples psychological fitness desires for attaining national. Research in Education 19 (1), December 232-235.

O “ Reilly, C. A \& Chatman, J. (2014).Passing organisational culture, Harvard Business School.

Ogbe, J.O (2014) Identification of unique health education researches for national development as perceived by health educators in tertiary institutions in Delta and Edo states of Nigeria. Delta State University, Abraka, Research in Education 20(1), December, 123-131.

Ogoina D, Pondei K, Chima G, Isichei C, Gidado S (2015) Knowledge, attitude and practice of standard precautions of infection control by hospital workers in two tertiary hospitals in Nigeria. Journal of Infectious Preview. 16,16-22.

Ogunyemi, B \& AIiyu, M.K. (2012). "Is Nigeria under Siege. The National Scholar. A Publication of the Academic Press.

Okechukwu, E. F \& Modteshi, C (2012) Knowledge and practice of standard precautions in public health facilities in Abuja, Nigeria. International Journal of Infection Control, 12, 8,1-7.

Oldham, G.R., Hackman, J.R \& Pearce, J.L. (2016). Condition under which health educators respond positively to enriched work. Journal of Applied Psychology, 61(4)395-403.

Oppenheim , B; Lidow, N; Ayscue, P; Saylors, K; Mbala, P \& Kumakamba, C (2019) Knowledge and beliefs about Ebola virus in a conflict-affected area: early evidence from the North Kivu outbreak. Journal of Global Health 2019 December, (2),020311.

Peters, T.J \& Waterman, R.H ( 2013) In search of excellence. New York : Harper and Row Publishers.

Reber, R.A ; Wallin, J.A \& Duhon, D.L (2013) Preventing occupational injuries through commitment management . Public Personnel Management, Summer, 30 11-312.

Rickli, S \& PerdeckNolost, J. (2012).Capital and Return on Investment for the Organisation.Tilburg University.

Robbins, S.P \& Judge, T.A. (2019). Organisation Behaviour. Upper Saddle River, New Jersey: Pearson Prentice Hall.

Sass, D. A., Seal, A. K \& Martin, N. K. (2010). Predicting teacher retention using stress and support variables. Journal of Educational Administration, 49(2), 200-215.

Shaw, J\& Newton, J. (2014). Teacher retention and satisfaction with a servant leader as principal. Education, 135(1), 101-106.

Shimizu K. (2020) nCoV, fake news, and racism. The Lancet 2020 Feb;395(10225), 685-686.

Steinhardt, M. A., Smith Jaggars, S. E., Faulk, K. E\& Gloria, C. T. (2011). Chronic work stress and depressive symptoms: Assessing the mediating role of teacher burnout. Stress and Health, 27, 420-429.

Suoke, O. P (2013) The role health educators in early childhood education for national security. Research in Education 19 (1), December32-33.

Sutcher, L., Darling-Hammond, L\& Carver-Thomas, D. (2016). A coming crisis in teaching? Health educators supply, demand, and shortages in the U.S. Palo Alto, CA: Learning Policy Institute.

The National Agency for Food and Drug Administration and Control, (2020). COVID 19 pandemic: NAFDAC and the extended lockdown. Vanguard Comments , Friday, April 22,2020 . 
The National HIV Sero-Prevalence Sentinel Survey (2003) Level of occurrence of HIV infection in Nigeria. A Report Submitted to the Federal Ministry of Health in Abuja.

The Nigerian Labour Congress (2012) Labour creates wealth .Communiqué of the Nigeria Labour Congress at the end of its National Executive Council (NEC) Meeting held in_Benin_City_Edo State On August 8, 2012, 9 .

Tucker, A \& Phillips, W. R (1999) Medical health educators and infection control: Risks and precautions. Tokai .Journal of Experimental Clinical of Medicine , 22, 169-76.

World Health Organisation (2020). Responding to COVID-19: Real-time training for the coronavirus disease outbreak URL: https://openwho.org/channels/Covid-19 [accessed 2020-02-01].

World Health Orgasisation (2020) Coronavirus disease 2019 (COVID-19): World Health Orgasisation. 2020. [Online]. Available from: https://www.who.int/emergencies/diseases/novel coronavirus-2019 [Accessed on 1st March 2020].

World Health Orgasisation (2020) Situation reports. 2020. [Online]. Available from: https://www.who.int/docs/default- $\quad$ source/coronaviruse/situation-reports/20200306- $\quad$ sitrep-46-Covid19.pdf?sfvrsn=96b04adf_2 [Accessed on 7th March 2020]. 